\title{
APPLICATION OF MAGNETIC RESONANCE IMAGING IN EVALUATING ANKLE MOTION INJURY
}

\author{
APLICAÇÃO DE IMAGENS DE RESSONÂNCIA MAGNÉTICA NA AVALIAÇÃO DE LESÕES POR \\ MOVIMENTO DO TORNOZELO
}

\section{APLICACIÓN DE LA RESONANCIA MAGNÉTICA EN LA EVALUACIÓN DE LA LESIÓN POR MOVIMIENTO DEL TOBILLO}

\begin{abstract}
Introduction: Discuss the application of magnetic resonance imaging in evaluating ankle motion injury. Objective: Verify the influencing factors of magnetic resource imaging (MRI) diagnosis based on the linear regression algorithm model. Methods: The experimental group was diagnosed by MRI, while the control group was diagnosed by plain X-ray. After that, the mathematical model of the linear regression algorithm was constructed. Results: It could be concluded that the MRI detection rate was $85.71 \%$, and the $\mathrm{X}$-ray plain film detection rate was $77.14 \%$. The linear regression model analysis showed that the P-value of cartilage injury, tendon fracture, bone contusion, and soft tissue swelling was greater than 0.05. Conclusions: MRI has more advantages in the application of ankle joint diagnosis. And ligament injury and joint effusion are the influencing factors of MRI diagnosis, which can highly indicate the authenticity of the injury in the ankle joint. Level of evidence II; Therapeutic studies - investigation of treatment results.
\end{abstract}

Keywords: Linear model; Magnetic resonance imaging; X-ray.

\section{RESUMO}

Introdução: Discutir a aplicação da ressonância magnética na avaliação da lesão motora do tornozelo. Objetivo: Verificar os fatores que influenciam o diagnóstico de imagens de recursos magnéticos (RM) com base no modelo de algoritmo de regressão linear. Métodos: O grupo experimental foi diagnosticado por ressonância magnética, enquanto o grupo controle foi diagnosticado por radiografia simples. Em seguida, foi construído o modelo matemático do algoritmo de regressão linear. Resultados: Concluiu-se que a taxa de detecção da ressonância magnética foi de 85,71\% e a taxa de detecção da placa de raios $X$ simples foi de 77,14\%. A análise do modelo de regressão linear mostrou que o valor P para lesão da cartilagem, fratura do tendão, contusão óssea e edema do tecido mole foi maior que 0,05. Conclusões: a ressonância magnética apresenta mais vantagens na aplicação do diagnóstico da articulação do tornozelo. E a lesão ligamentar e derrame articular são os fatores que influenciam o diagnóstico de ressonância magnética, o que pode indicar amplamente a autenticidade da lesão articular do tornozelo. Nível de evidência Il; Estudos terapêuticos: investigação dos resultados do tratamento.

Descritores: Modelo Linear; Imagem por ressonância magnética; raio-X.

\section{RESUMEN}

Introducción: Discutir la aplicación de la resonancia magnética en la evaluación de la lesión por movimiento del tobillo. Objetivo: Verificar los factores que influyen en el diagnóstico de imágenes de recursos magnéticos (IRM) basado en el modelo de algoritmo de regresión lineal. Métodos: El grupo experimental fue diagnosticado por resonancia magnética, mientras que el grupo control fue diagnosticado por radiografía simple. Después de eso, se construyó el modelo matemático del algoritmo de regresión lineal. Resultados: Se pudo concluir que la tasa de detección de resonancia magnética fue del 85,71\% y la tasa de detección de la placa simple de rayos $X$ fue del $77,14 \%$. El análisis del modelo de regresión lineal mostró que el valor P de la lesión del cartílago, la fractura del tendón, la contusión ósea y la hinchazón de los tejidos blandos fue superior a 0,05. Conclusiones: la RM tiene más ventajas en la aplicación del diagnóstico de la articulación del tobillo. Y la lesión de ligamentos y el derrame articular son los factores que influyen en el diagnóstico de resonancia magnética, que pueden indicar en gran medida la autenticidad de la lesión en la articulación del tobillo. Nivel de evidencia Il; Estudios terapéuticos: investigación de los resultados del tratamiento.

Descriptores: Modelo lineal; Imagen por resonancia magnética; rayos X. 


\section{INTRODUCTION}

Nowadays, regression model has been widely used, involving economics, biology, medicine, finance, engineering, and other disciplines[1]. Linear regression model, as a relatively simple model algorithm, has been studied and used for a long time. Its function form is known and its parameters are unknown [3-4]. When the assumptions of the model are consistent with the actual situation, the prediction results obtained by the corresponding model will have a higher accuracy. However, the disadvantages of linear regression model are also obvious. When the assumptions of the model are inconsistent with the actual situation, if the model is used to make predictions, the results will be very bad. MRI is another significant advance in medical imaging after $X$-ray plain film and CT [5]. Since the 1980s, MRI has been widely used in the field of injury diagnosis at home and abroad. For example, Agha et al. (2018) [6] used MRI to detect the relationship between patients with peroneal tendon injury and lateral variation of the ankle joint, and the results showed that lateral anatomical variation of the ankle joint resulted in peroneal tendon injury. Shim et al. (2018) [7] used MRI to analyze ankle joint injuries in 170 patients, and the results showed that MRI could detect ankle joint injuries with high sensitivity and specificity. Salonen et al. (2017) [8] scanned 20 patients with traumatic lateral patellar detachment with 1.5T MRI, and found that recurrent lateral patellar dislocation led to the occurrence of systemic knee arthrosis. Wang et al. (2015) [9] used MRI to provide visualization of the human musculoskeletal system, indicating the biochemical composition of cartilage. Wang et al. (2019) [10] studied the effect of MRI on the paraspinal muscles of the lumbar spine, and the results showed that the shear stiffness of superficial MRI of the paraspinal muscles could be reduced. Shen et al. (2018) [11] analyzed the related factors of anterior cruciate ligament ( $A C L$ ) injury through $M R I$, and the results showed that the stenosis of intercondylar incision was the related factor of ACL injury.

\section{METHODS}

\section{Basic information}

70 cases of ankle injury patients admitted to hospital from December 2018 to December 2019 were selected, all of which were divided into experimental group and control group, with 35 cases in each group. There were 19 males and 16 females in the experimental group, and 17 males and 18 females in the control group.

Inclusion criteria: patients with obvious lower joint sprain; patients confirmed by clinical examination, surgery and other data; and patients aged 18 years old or older.

Exclusion criteria: patients with contraindications to MRI; patients who have received surgical treatment; patients with a history of ankle fracture and infection; and patients with congenital skeletal deformities.

\section{MRI examination}

The selected patients with ankle joint movement injury were examined by US GE 1.5 T superconducting MRI equipment.The imaging sequence and parameters are shown in Table 1.

\section{Evaluation criteria of MRI image quality}

A 5-point Likert scale was used to evaluate the display capacity and image quality of various anatomical structures of joints, as shown in Table 2 below. If the image quality reaches 3 points or above, it is deemed to meet the needs of clinical diagnosis. Two senior neuroradiologists were selected to read the films in a double-blind way. When they disagreed, they could decide by negotiation.

\section{Construction of regression models}

In this study, six imaging features diagnosed by MRI. The corresponding injury characteristics of 25 patients were set as 1, while no
Table 1. Sequence and parameters of $1.5 T$ superconducting MRI.

\begin{tabular}{c|c|c|c}
\hline Parameters & Horizontal axis & Coronal & Sagittal \\
\hline Matrix & $288^{\prime} 288$ & $288^{\prime} 256$ & $288^{\prime} 288$ \\
\hline Bandwidth $(\mathrm{kHz})$ & 50 & 31.25 & 31.25 \\
\hline TR/TE $(\mathrm{ms})$ & $2000 / 35$ & $2255 / 60$ & $500 / 60$ \\
\hline Layer thickness $(\mathrm{mm})$ & 3 & 4 & 4 \\
\hline Layer spacing $(\mathrm{mm})$ & 0.3 & 0.4 & 0.4 \\
\hline FOV $(\mathrm{m})$ & $0.16^{\prime} 0.16$ & $0.16^{\prime} 0.16$ & $0.16^{\prime} 0.16$ \\
\hline
\end{tabular}

Table 2. Evaluation criteria of MRI quality of ankle joint

\begin{tabular}{|c|c|c|}
\hline Score & $\begin{array}{l}\text { Classification of } \\
\text { image quality }\end{array}$ & Graphic evaluation \\
\hline 1 & Worst & $\begin{array}{c}\text { There were numerous artifacts and noise } \\
\text { disturbances that failed to show where cartilage, } \\
\text { ligaments, and tendons were located }\end{array}$ \\
\hline 2 & Worse & $\begin{array}{l}\text { There were partial artifacts and noise interference, } \\
\text { showing } 50 \% \text { of the cartilage, ligaments, and tendons }\end{array}$ \\
\hline 3 & General & $\begin{array}{l}\text { There were slight artifacts and noise } \\
\text { interference, showing } 60-80 \% \text { of the } \\
\text { cartilage, ligaments, and tendons }\end{array}$ \\
\hline 4 & Moderate & $\begin{array}{l}\text { The cartilage, ligaments, and tendons were fully } \\
\text { displayed with little artifact or noise interference }\end{array}$ \\
\hline 5 & Best & $\begin{array}{c}\text { Free of artifacts and noise, the cartilage, ligaments, and } \\
\text { tendons were fully displayed with high resolution }\end{array}$ \\
\hline
\end{tabular}

corresponding injury characteristics were set as 0 , and the MRI image analysis results were used as the dependent variable.

Assuming a linear correlation exists between a random variable $y$ and $m$ non-random variables ix, then the relationship between them can be expressed by multiple linear regression model, namely:

$$
y=\ln \left(p_{i} / 1-p_{i}\right)=a_{0}+a_{1} x_{1}+a_{2} x_{2}+\cdots+a_{n} x_{n+\Delta}
$$

In equation (1), $y$ is the dependent variable, $x_{1}, x_{2}, \ldots, x_{n}$ are independent variables, $a_{\theta}, a_{1}, \ldots, a_{n}$ are coefficients, $P_{i}$ represents the probability of event occurrence, and D represents random error.

For precision analysis, the error in the multiple linear regression model can be defined as follows.

$$
\sigma=\sqrt{\frac{\sum_{i=1}^{n}\left(y_{i}-y_{i}\right)^{2}}{n-(m+1)}}=\sqrt{\frac{V^{T} V}{n-(m+1)}}
$$

In equation (2), $\mathrm{N}$ is the observed value and the number is $\mathrm{n}, \mathrm{m}+1$ is the number of parameters, and $\mathrm{N}-(\mathrm{m}+1)$ is redundant observation.

According to the parameter adjustment theory, the variance estimation formula of $a$ and $y$ is as follows:

$$
\begin{aligned}
& \sum(\hat{a})=\sigma^{2} Q_{\hat{a} \hat{a}} \\
& \sum(\hat{y})=\sigma^{2} B Q_{\hat{a} \hat{a}} B^{T}
\end{aligned}
$$


The formula for analyzing and testing whether the variables contained in the model really have linear correlation with dependent variables and the fitting effect of the regression model is as follows:

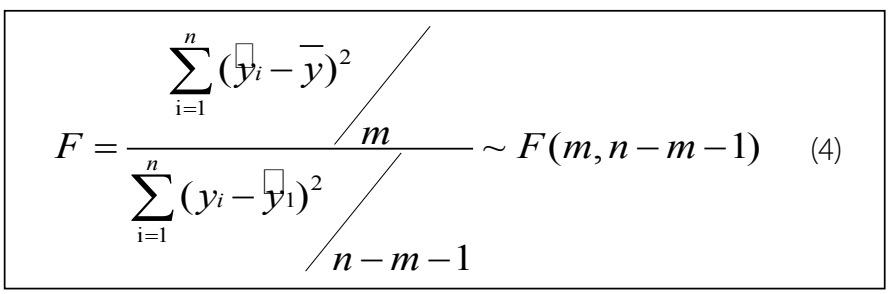

After looking up to the table, $F>F_{1-a}(m, n-m-1)$ can be obtained. If $F>$ $F_{1-a}(m, n-m-1)$, then the given significance level a rejects $H_{0}$, and the linear overall regression effect of this $\mathrm{m}$-element is considered significant. If $\mathrm{F}<\mathrm{F}$ ${ }_{1-a}(m, n-m-1)$, then $H_{0}$ is accepted at the given significance level $a$, and the linear overall regression effect of this $m$-element is considered significant.

\section{Statistical analysis}

SPSS19.0 software was used to analyze the data of 70 patients with ankle joint injury. The counting information was expressed as a percentage. And $P<0.05$ was considered statistically significant.

\section{RESULTS}

\section{Comparison of basic physical characteristics of two groups of patients}

For the experimental group, the average age was $32.54 \pm 8.08$ years old, the weight was $59.68 \pm 7.82 \mathrm{~kg}$, the height was $167.69 \pm 8.73 \mathrm{~cm}$, and the time from injury to treatment was $5.06 \pm 1.45$ days. For the control group, the average age was $32.31 \pm 5.17$ years old, the weight was $58.95 \pm 6.97 \mathrm{~kg}$, the height was $166.88 \pm 8.67 \mathrm{~cm}$, and the time from injury to treatment was $5.03 \pm 1.67$ days. There were no statistically significant differences in age, height, weight, gender, and time from injury to treatment between the two groups $(P>0.05)$, which were comparable, as shown in Figure 1 below.

\section{Comparison of patients with ankle injuries diagnosed by MRI and X-ray}

MRI could correctly detect 30 cases of ankle joint injury, and the detection rate was as high as $85.71 \%$. There were 26 cases of ligament injury, including lateral ligament of ankle joint, calcaneofibular ligament, and posterior talofibular ligament. There were 23 cases of osteochondral injury and 20 cases of tendon rupture, including long fibula tendon, flexor tarsalis longus tendon, short fibula tendon and Achilles tendon injury. There were 21 cases of bone contusion, including femoral contusion, tibia contusion, iliac crest, lumbar spine, cervical spine, radius, and other structural injuries. There were 24 cases with joint effusion and 20 cases

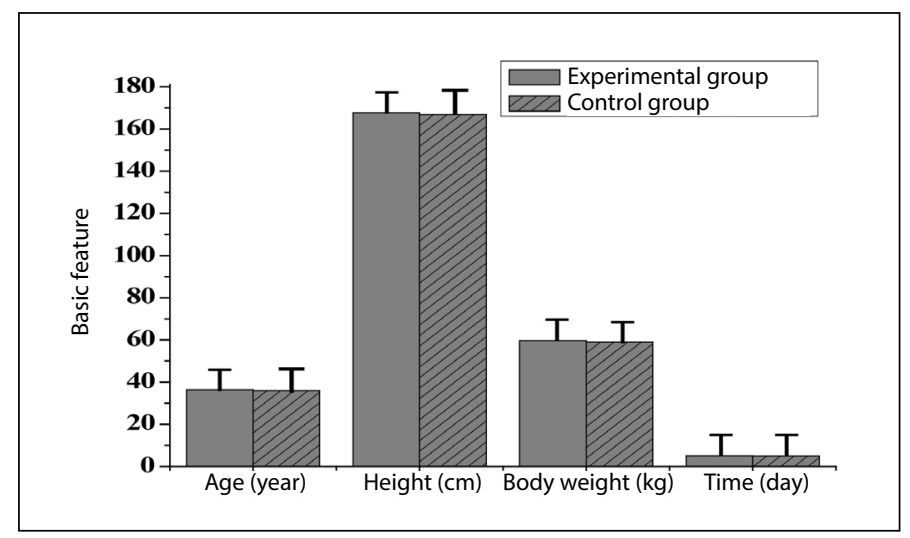

Figure 1. Comparison of basic characteristics between the two groups. with surrounding soft tissue swelling. In addition, 27 cases of ankle joint injury were correctly detected by $\mathrm{X}$-ray plain film technique, with a detection rate of $77.14 \%$.

\section{Analysis of MRI images}

All images were read independently by two senior radiologists, and consensus was reached through consultation in case of disagreement. Six imaging features of osteochondral injury (figure 2), tendon rupture (figure 3), ligament injury and joint effusion (figure 4), bone contusion and surrounding soft tissue swelling (figure 5) diagnosed by MRI in patients with ankle joint sports injury were analyzed.

\section{Regression analysis of related factors affecting MRI diagnosis}

The 35 patients had 6 kinds of MRI features. The linear regression model analysis was carried out by taking the six imaging characteristics of MRI as independent variables and the analysis results of MRI images as dependent variables. It was found that the $P$ values of osteochondral injury, tendon fracture, bone contusion, and soft tissue swelling in the patients were all

Table 3. Comparison of diagnostic detection rates of MRI and X-ray.

\begin{tabular}{c|c|c}
\hline Diagnostic mode & MRI & X-ray plain film \\
\hline Total cases & 35 & 35 \\
\hline The number of cases detected & 30 & 27 \\
\hline Detection rate (\%) & 85.71 & 77.14 \\
\hline
\end{tabular}

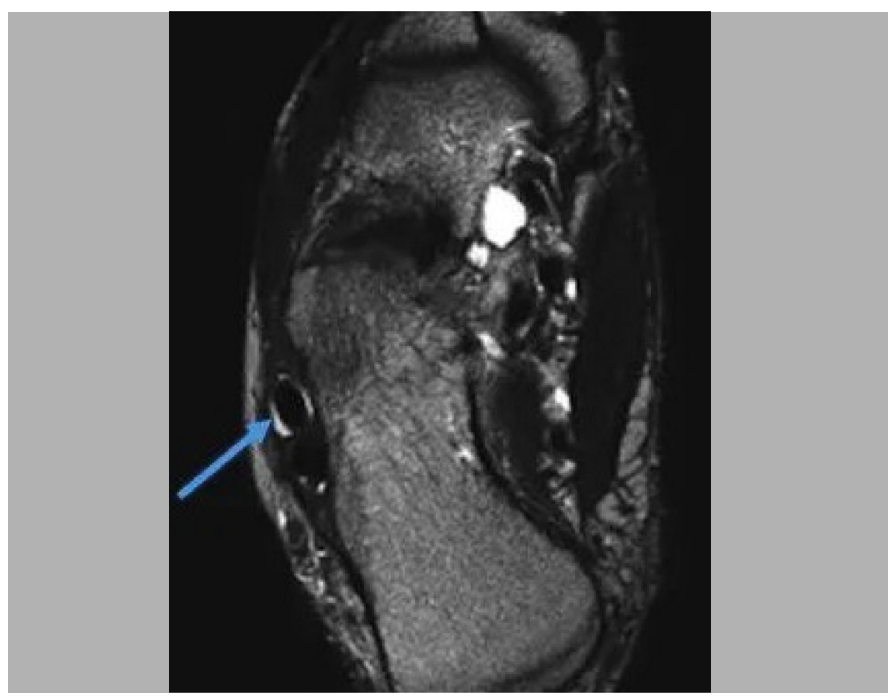

Figure 2. Image of osteochondral injury in a 32-year-old male patient (arrow).

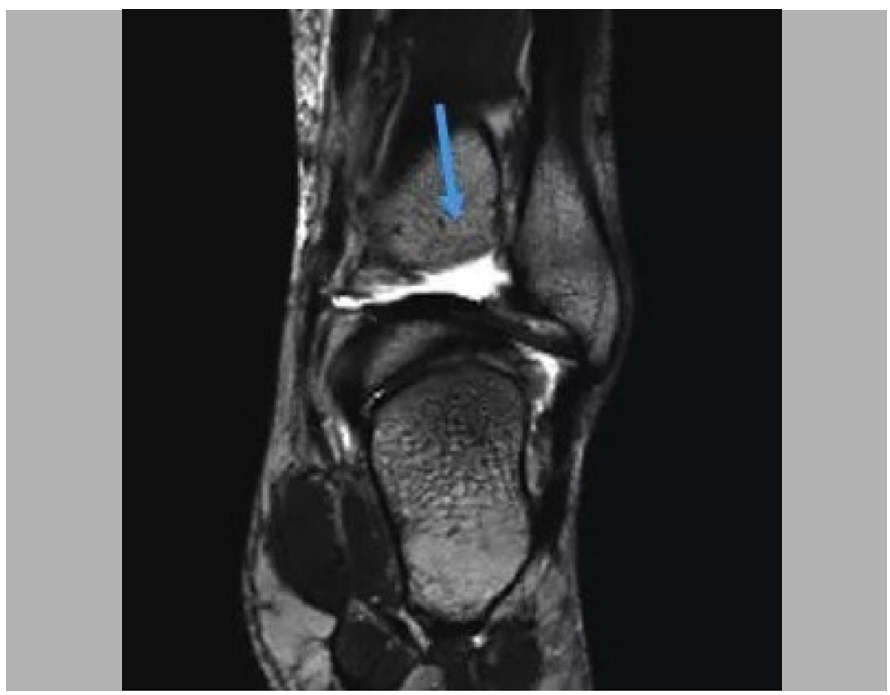

Figure 3. Image of a 26-year-old male patient with tendon rupture and tendon sheath effusion (arrow). 


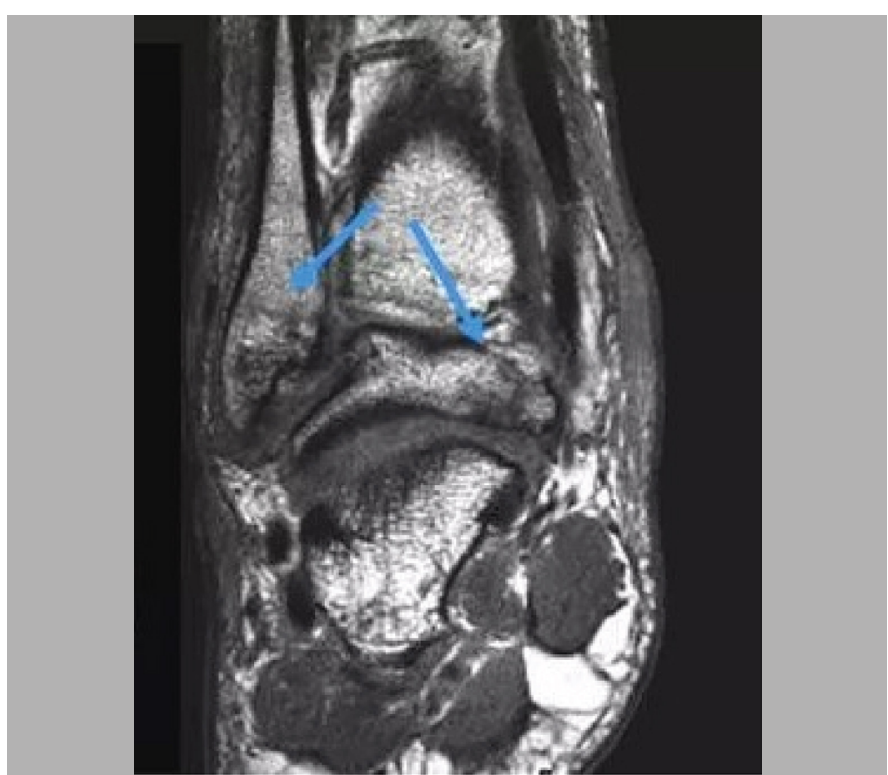

Figure 4. Image of a 37-year-old female patient with lateral ligament injury and joint cavity effusion.

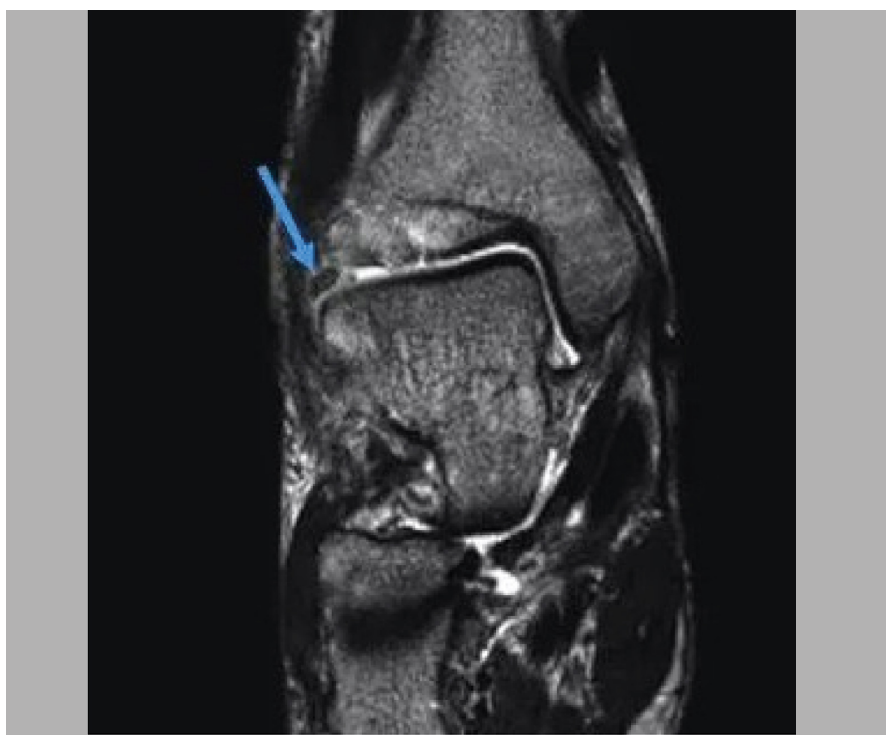

Figure $\mathbf{5}$. Image of bone contusion in a 46-year-old male patient. greater than 0.05 . The $P$ value of ligament injury and joint effusion in the patients was less than 0.05 , and the regression coefficients were 0.367 and 0.298 , respectively. Both of them were positively correlated with MRI diagnosis results, and the correlation of ligament injury was higher.

Table 4. Linear regression analysis of image characteristics.

\begin{tabular}{c|c|c|c|c}
\hline Image features & Cases & $\begin{array}{c}\text { Regression } \\
\text { coefficients }\end{array}$ & $\mathbf{t}$ & $P$ value \\
\hline Osteochondral injury & 23 & 0.125 & 0.933 & 0.359 \\
\hline Ligament injury & 26 & 0.367 & 2.767 & 0.010 \\
\hline Tendon rupture & 20 & 0.218 & 1.698 & 0.101 \\
\hline Bone contusion & 21 & 0.093 & 0.770 & 0.448 \\
\hline Joint effusion & 23 & 0.298 & 2.177 & 0.038 \\
\hline Soft tissue swelling & 20 & 0.173 & 1.536 & 0.136 \\
\hline
\end{tabular}

\section{DISCUSSION}

In this study, the detection accuracy of MRI technology was higher than that of X-ray plain film, which was consistent with the comparison of X-ray plain film, ultrasound, and MRI made by Scholz et al. (2015) [12].For example, the misdiagnosis rate in this study was as high as 23.86\%[13]

According to the images of patients, MRI showed good effects on ligament tear, tendon rupture, cartilage injury, tendon sheath effusion, and other problems, with high resolution. This is basically consistent with the diagnostic image of MRI obtained by Giuseppe et al. (2018) [14]

\section{CONCLUSIONS}

In this study, linear regression algorithm model was used to explore the application value and related factors of MRI in the diagnosis of patients with ankle joint motion injury.MRI has a better diagnostic performance than the common diagnostic $X$-ray plain film. In addition to fully displaying the ankle joint structures such as ligaments, tendons, surrounding soft tissues, and accompanying sheath effusion, it also has a higher sensitivity to recessive fractures and micro-fractures that can't be detected by plain X-ray film. Ligament injury and joint effusion are the influencing factors of MRI diagnosis, and ligament injury and joint effusion in the ankle joint can highly indicate the injury status of patients.

The author declare no potential conflict of interest related to this article

\section{REFERENCES}

1. Hidetoshi M. Sparse group lasso for multiclass functional logistic regression models. Commun Stat Simul Comput. 2019;48(6):1784-97.

2. Zhang Y, Sun R, Zhang L, Feng L, Liu Y. Effect of blood biochemical factors on nontraumatic necrosis of the femoral head : Logistic regression analysis. Orthopade. 2017;46(9):737-743.

3. Tian $\mathrm{H}, \mathrm{Xiao} \mathrm{R}, \mathrm{Hu} \mathrm{X}$, et al. Logistic regression analysis of ultrasonography in diagnosis of malignant thyroid nodules. Chinese Journal of Interventional Imaging and Therapy. 2017;14(12):742-6.

4. Zhang S, Yang L, Peng C, Wu M. Logistic regression analysis of risk factors for postoperative recurrence of spinal tumors and analysis of prognostic factors. Oncol Lett. 2018;15(2):1716-22.

5. Willwacher S, Mählich D, Trudeau BM, Hamill J, Weir G, Brüggemann GP, et al. The habitual motion path: evidence from an MRI study on cartilage volume changes after 75 minutes of running in different footwear conditions. Footwear Science. 2019 [cited 2021 Jun 14];11(sup1):S55-6. Available from: https://www.tandfonline.com/doi/abs/10.1080/19424280.2019.1606075

6. Agha $M$, Abdelgawad $S M$, Aldeen NG. Lateral ankle anatomical variants predisposing to peroneal tendon impingement. Alex J Med. 2018;54(4):619-26.

7. Shim DW, Kim S, Hwang Y, Lee Y, Lee JW, Han SH. Detection of the Tram Track Lesion in the Ankle Joint:
Comparing 3.0-Tesla Magnetic Resonance Imaging and Arthroscopy. Arthroscopy. 2018;34(3):866-71.

8. Salonen EE, Magga T, Sillanpää PJ, Kiekara T, Mäenpää H, Mattila VM. Traumatic Patellar Dislocation and Cartilage Injury: A Follow-up Study of Long-Term Cartilage Deterioration. Am J Sports Med. 2017;45(6):1376-82.

9. Wang L, Regatte RR. T 1 P MRI of human musculoskeletal system. J Magn Reson Imaging. 2015;41 (3):586-600 10. Wang CK, Fang YD, Lin LC, Lin CF, Kuo LC, Chiu FM, et al. Magnetic resonance elastography in the assessment of acute effects of kinesio taping on lumbar paraspinal muscles. J Magn Reson Imaging. 2019;49(4):1039-45.

11. Shen L, Jin ZG, Dong QR, Li LB. Anatomical risk factors of anterior cruciate ligament injury. Chin Med J (Engl). 2018;131(24):2960-2967.

12. Scholz AM, Bünger L, Kongsro J, Baulain U, Mitchell AD. Non-invasive methods for the determination of body and carcass composition in livestock: dual-energy X-ray absorptiometry, computed tomography, magnetic resonance imaging and ultrasound: invited review. Animal. 2015;9(7):1250-64.

13. Wong SBS, Peh WCG. The role of magnetic resonance imaging in the evaluation of scaphoid fractures. J Med Radiat Sci. 2019;66(1):3-4. 